\title{
The Development of Customer Satisfaction Measurement Model for Small Online Apparel Businesses in Malaysia
}

\author{
Noorshella Binti Che Nawi ${ }^{1} \&$ Abdullah Al Mamun ${ }^{1}$ \\ ${ }^{1}$ Faculty of Entrepreneurship and Business, Universiti Malaysia Kelantan, Malaysia \\ Correspondence: Noorshella Binti Che Nawi, Faculty of Entrepreneurship and Business, Universiti Malaysia \\ Kelantan, Locked Bag 36, Penglalan Chepa, 16100 Kota Bharu, Kelantan, Malaysia. E-mail: \\ norshella@umk.edu.my
}

Received: June 10, 2014

Accepted: September 2, 2014

Online Published: September 25, 2014

doi:10.5539/ijbm.v9n10p39

URL: http://dx.doi.org/10.5539/ijbm.v9n10p39

\begin{abstract}
Consumers worldwide are showing great interest in E-commerce and many believe that E-commerce plays a significant part in the global economy. This study compared earlier consumer satisfaction measurement models and developed a model for small online apparel business in Malaysia. Studies compared satisfaction in online settings, which focused on the pre-purchase phase and post-purchase phase. However, none of the studies were conducted at the point-of-purchase and post-purchase phases. Hence, this study proposed a better model for measuring customer satisfaction by dividing it into two phases, which are at the point-of-purchase phase and post-purchase phase.
\end{abstract}

Keywords: E-commerce, customer satisfaction, e-service quality, attitude, behavioral intention, point-of-purchase, post-purchase

\section{Introduction}

Although the rapid growth of e-retailing may reflect convincing advantages of shopping on the Internet versus brick and mortar stores, consumers, however, are sometimes frustrated with e-shopping. The same problem occurs when customers purchase apparel online. Customers take a risk when purchasing apparel online because they cannot try on the garment to check the fit, texture or colour (Kim et al., 2006). Recently, some researchers have realized that customer satisfaction plays a crucial role in sustaining the marketplace (Garver and Gagnon 2002). According to them, there is a significant relationship between customer satisfaction and organizational performance. Thus, it is important to make sure that customers are satisfied with the services that have been delivered. If not, retailers will lose their market. Kim and Stoel (2004) stated that customers must be satisfied with their shopping experience, otherwise they will not return. Yang (2001) and Grewal (2000) found that service quality in an online environment is a precondition for e-commerce business. Research on the interactions among different dimensions of e-service quality in predicting overall service quality, customer satisfaction, and purchase intentions in an online context remains in its infancy. In addition, the researcher has noted that many of the prior service quality measures take into account the entire purchase and even the after-purchase process (Suh \& Han 2003; Muyllea et al., 2004; Parasuraman et al., 2005; Kim et al., 2006). Bauer et al. (2006) present a view of the four purchase phases and try to connect with the satisfaction and value perceptions but do not indicate how each dimension fits into the phases. No study has been conducted at the point-of-purchase and post-purchase. Hence, the broad aim of this study is to develop a framework to represent the factors that contribute to customer satisfaction with small online apparel businesses in Malaysia at the point-of-purchase and post-purchase. Kotler (1991) argued that satisfaction is the consequence of the customer's experiences during various purchasing processes. Thus, satisfaction in the online environment should be measured before purchase, during purchase and after purchase. This view is shared by Bauer et al., (2006) who affirmed that a complete definition of e-service quality should cover all cues and encounters that occur before, during and after the electronic service delivery. The remainder of the paper is organized as follows: Section 2 reviews the development of the research framework and clarification of the point-of-purchase and post-purchase phase. Section 3 describes the methodology taken, Section 4 discusses the result and finding and lastly, Section 6 provides the conclusion of this study. 


\section{The Development of the Research Framework}

Empirical research is needed to shed light on the detailed determinants of e-service quality and its impact on perception by customers of the online environment setting. This is to reflect the limitations of the existing literature to provide a conceptual model of e-service quality. This study proposes that e-service quality dimensions include information search and alternative evaluation, purchase, expected delivery and expected customer service and also develops a research model for understanding the perceptions of rational customers at the time they purchase products through online services. The model also proposes that e-service quality dimensions are causally linked to customer satisfaction and in turn affect the behavioural intention of customers. The dimensions of post purchase, i.e. service delivery and customer service, are added as links to customer satisfaction and in turn influence customer purchase intentions.

The conceptualization and measurement of e-service quality is still in its infancy. The first gap identified by the researcher is that most scales do not consider the entire purchase process, including post purchase. This view is shared by Barrutia and Gilsanz (2009) who stated that some scales and dimensions do not investigate the complete purchase experience and few studies have examined and investigated the complete purchase experience among customers. For example, Xia et al. (2008) postulated a framework to measure customer satisfaction in the online environment in China's context which includes the entire process of purchase experience, and the eTailQ scale was developed by Wolfinbarger and Gilly (2003) to also consider the complete purchase experience of customers.

In this study, the development of the research framework was adapted from the three studies conducted by Xia, et al. (2008, see Figure 1), Holloway and Beatty (2008, see Figure 2), and Carlson and O'Cass (2010, see Figure $3)$, together with this researcher's common sense. However, there are some weaknesses identified on the framework developed by Xia et al. (2008). They combined the post-purchase with two other stages (information search and evaluation and transaction) to measure overall satisfaction. As noted, post purchase includes service delivery and customer service and should be measured separately from the other stages. This is because these two dimensions occur after the customers have received the products they have bought through a website. In other words, customers can evaluate their satisfaction about these two dimensions after they have experienced them. In addition, this researcher believes that the two other stages are best measured for satisfaction when customers make their purchases. The consequences of e-service quality are in attitudes and behavioural intentions. They are included in this study to capture customers' perceptions when they make their purchases.

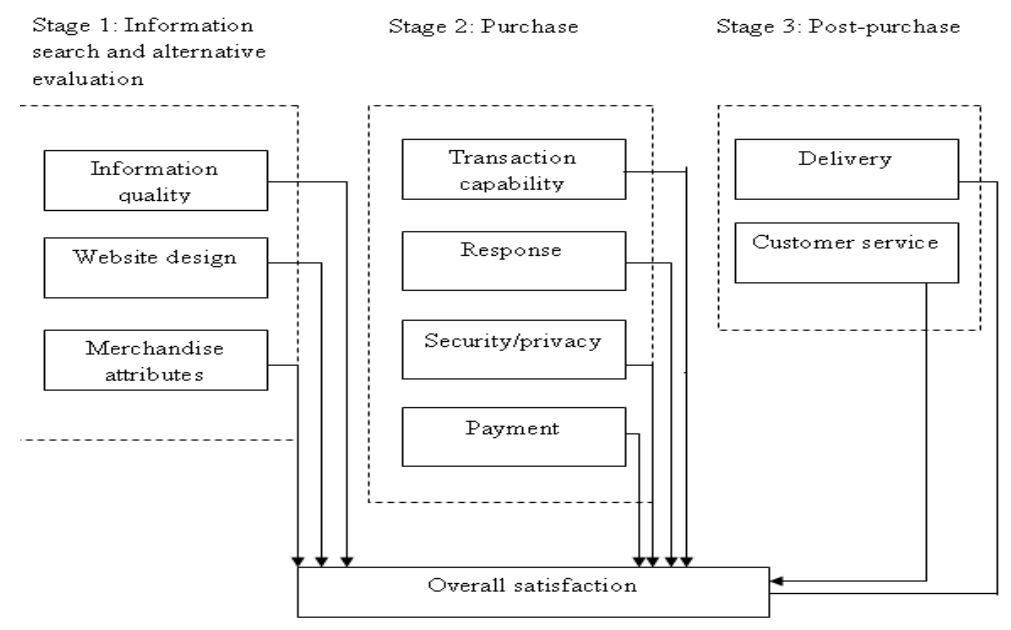

Figure 1. Research model proposed by Xia et al. (2008) 


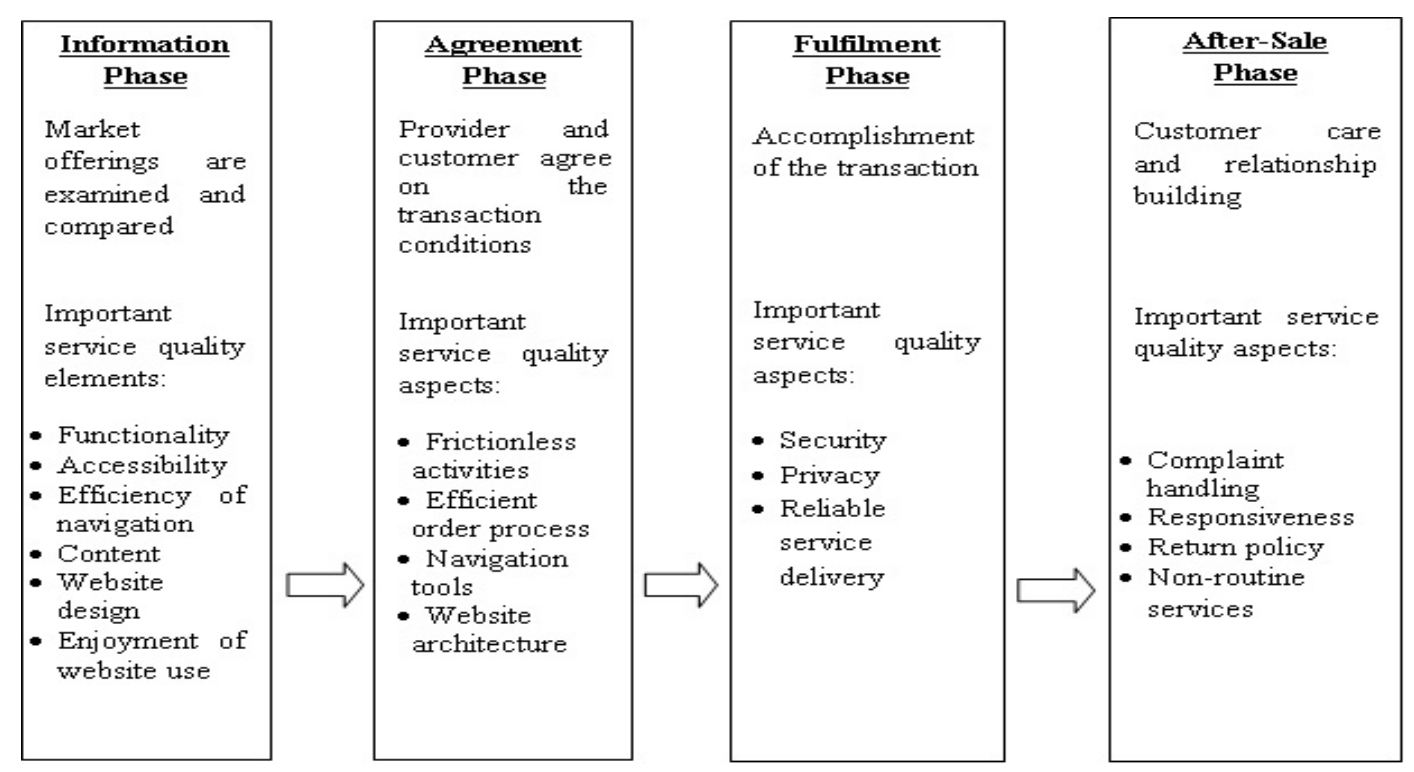

Figure 2. Research model proposed by Holloway and Beatty (2008)

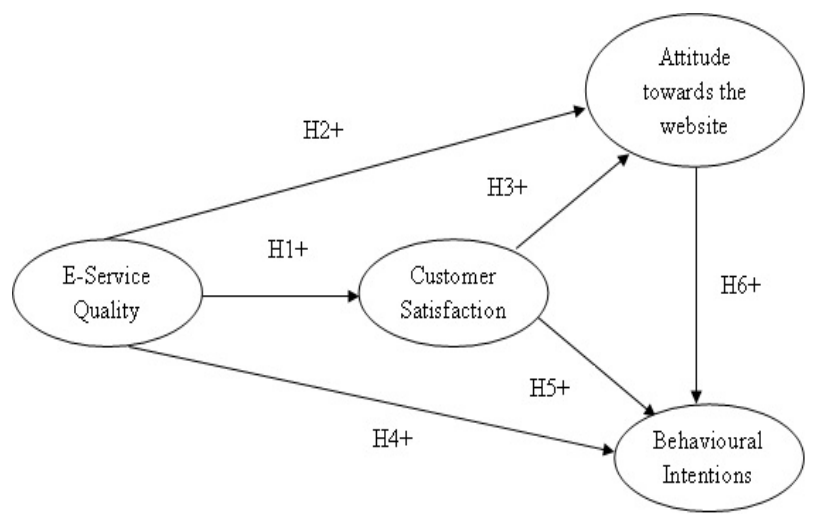

Figure 3. Research model proposed by Carlson and O'Cass (2010)

Many of the previous studies have concentrated on the development of e-service quality scales rather than on consequences of the e-service. Indeed, concentration on intentions (to revisit or repurchase), attitude (such as saying positive things about the site), and customer satisfaction are less studied by researchers. They are more likely to focus on other constructs such as loyalty, perceived value, and trust (Swaid \& Wigand, 2009). Therefore, to fulfill this gap, this study investigates the consequences of e-service quality including overall satisfaction, behavioral intention, and attitude. This concept is supported by Carlson and O' Cass (2010) who agreed that there is a need for investigation into e-service quality, satisfaction and behavioral intention in conjunction with consumer attitudes. This researcher also believes that these outcome measures are an area of research that needs attention because many studies have previously focused on rating the features of websites rather than investigating outcome measures.

The arrangements of all the items in the information search and alternatives and evaluation stage (Stage 1) and purchase stage (Stage 2) are adapted from the study by Xia et al. (2008, see Figure 2). Then, these items (information quality, website design, merchandise attribute, transaction capability and payment, security/privacy) are combined into one dimension and known as e-service quality. Three new items-general belief, expected customer service, and expected delivery service - are also included in this dimension.

\subsection{General Belief}

Beliefs about an e-store or online shopping experience are best defined as an individual's subjective evaluation of a specific e-store or an online shopping experience. Gefen (2002) defined belief as an individual's subjective evaluation of an electronic vendor in which the evaluation includes trust toward the vendor, perceived risk with 
the vendor, empathy, reliability, responsiveness, and assurance with the vendor. Beliefs about Internet shopping also refer to the customers' evaluation ( $\mathrm{Li}$ and Zhang 2006). They added that in terms of B2C, it is defined as a (potential) consumer's subjective evaluation of a relevant object, such as the Internet used as a shopping channel, a specific e-store or online shopping experience. Beliefs are expected to affect (potential) customers' shopping intentions, behavior and satisfaction (Han \& Noh 2000; Devaraj et al., 2002). Drawing on the literature presented above, I propose that:

"Belief" refers to the general belief about online shopping. It refers to an individual's overall subjective evaluation of an e-store as a whole and included as one of the e-service quality attributes."

\subsection{Information Quality, Website Design and Merchandise Attributes}

Consumers use a variety of methods to gather information: they seek information from trusted and respected personal sources such as family, friends and peers; they use the Internet to compare service offerings and search for independent reviews and ratings; they rely on firms with a good reputation; they look for guarantees and warranties (Wirtz, Chew \& Lovelock, 2012). According to Xia, Fang and Peihong (2008), consumers not only exhibit a greater propensity to search for more information than they do in the goods context, but they also tend to explore more personal sources of information such as friends, family and co-workers before making any decision to purchase. Sufficient information on website will encourage customer to shop through online (Kuo \& Chen, 2011). Online shoppers largely depend on information available on the website, due to a need for adequate product information to make a purchase decision. If the shoppers are not satisfied with the information the website has provided, they will exit and visit a competitor's website.

According to Gregory, Wang, and DiPietro (2010), the design of the website is associated with consumer perception of the organization and order at the site. The website design also is a key factor that impacting customer satisfaction towards website experience. Without tangible cues such as a physical store front and product demonstrations, website aesthetics such as a well-organized layout and animated presentations demonstrating the product in action is critical in cognitive engagement and inducing positive associations with websites (Coker, 2013). Similarly, Sindhuja and Dastidar (2009) defined web usability as making the design simple so that customers who naturally tend to be goal-driven can accomplish their task as quickly and painlessly as possible. Shneiderman (2005) added that usability can be a balancing act where inadequate functionality will make the application useless while complexity and non-user-friendliness can make the interface hard to use.

\subsection{Transaction Capability and Payment, Response and Security and Privacy}

Many researchers find that security and privacy have indeed been important for online sales in recent years (Akinci, Atilgan-Inan, \& Aksoy, 2010; Cho \& Menor, 2010; Hsu, Hung, \& Tang, 2012; Ladhari, 2010). Security system is one of the most important issues. Nikhashemi et al. (2012) supported that security has positive influence on consumer attitude and perception toward internet shopping. Similarity, Martin, Camarero, \& Jose (2011) said that the influence of satisfaction on privacy will remains constant regardless of other factor.

Both online consumers and non-online-consumers have claimed that they would adopt online shopping if they could be assured that a company on the Web was reputable and the transaction system was secure. Guo, Ling \& Liu (2012) added that consumers choose the type of payment after they consider the convenience of payment as well as the security. Most of the virtual shops have not acquired the trust of customers (including Malaysians). With this kind of uncertainty, businesses are naturally reluctant to join e-commerce.

Thus, online apparel retailers are becoming more aware of the importance of providing consumer privacy policies (Ranganathan \& Ganapathy, 2002). Studies show that privacy or security has a strong impact on response to the overall quality of the site (Wolfinbarger \& Gilly, 2003), purchase (Loiacono, et al., 2007), and satisfaction (Szymanski \& Hise, 2000). Satisfaction will increase if the website offers a convenient payment mechanism.

It is generally accepted that website speed is of major importance for a successful website. Internet user's patience levels are constantly decreasing and the majority of visitors will leave your website if it doesn't load within 3 seconds (Jorg, 2013). Similar study by Dellaert and Kahn (1999) found that online shoppers are well known for having low tolerance and it is estimated that they only wait for eight seconds for a system to respond before bailing out. Therefore, a web page designer has to consider not only appearance and functionality but also loading time (Weinberg, 2000). As a result, it will raise the customer's degree of satisfaction and improve the website's transaction capability, ensure completion of all online shopping operations and save the customer's operation time (Xia et al., 2008). 


\subsection{Expected Service Delivery and Expected Customer Service}

Expected service delivery and expected customer service are measured when customers place their orders in contrast to service delivery and customer service at the post-purchase stage, which happens after customers have received their products. At the expected service delivery stage, this researcher proposes that satisfaction can occur if customers are offered a variety of service delivery methods and set out to test this. Besides having a standard delivery, an e-retailer can offer express delivery and cash on delivery (COD) based on customers' preferences on how the product is to be delivered. In addition, the price stated for delivery charges has to be reasonable without any hidden costs. Wang and Huarng (2002) found that aspects that satisfied customers were on-time deliveries with a competitive price and without any hidden charges. An extra incentive to delight customers is by providing free delivery if customers purchase more than one item from the website.

Meanwhile, expected customer service is more than policies, procedures and responsiveness in handling complaints. It also refers to the return policy, customer's right to change and that problems can be solved. At this stage too, customers are offered many interactive communications with the company. For instance, customers can use the chat room, email, telephone, bulletin board and feedback forms to communicate with the company (Massey and Levy 1999). According to Teo et al. (2003), interactivity features have a significant relationship with the consumers' perceived value. Indeed, Zeithaml (1988) added that customer value has been recognized as the key for businesses to succeed. Ray (2010) summarized that the availability of the online chat room on the website presence can boost customer satisfaction.

\subsection{Overall Satisfaction}

According to Ofir and Simonson (2007) and Johan (2006), exploration of satisfaction in the e-commerce environment is still in the emergent stage. Winter (2001) added that, in the context of online retailing, one of the centres of a firm's relationship programmes is customer satisfaction. Kim et al. (2009) defined satisfaction as the perception of pleasurable fulfilment in the customers' experiences. Broadly speaking, customer satisfaction is described as how products or services supplied by a company meet customer expectations.

Customer satisfaction is always connected with trust and loyalty. In explaining the establishment of e-loyalty, both e-satisfaction and e-trust play a pivotal role (Jin et al., 2008). For instance, studies discovered that e-satisfaction and e-trust influence e-satisfaction. Kim et al. (2009) proposed a study on the e-loyalty process by conceptualizing that e-loyalty is influenced by e-satisfaction, e-trust and multidimensional aspects of retail quality. They found that the e-loyalty development process is influenced by both e-satisfaction and e-trust.

\subsection{Attitude}

In researching consumer behavior, the relationship between attitude to a given system and behavioral intention can be found in TAM (Davis et al. 1989). Studies conducted by Castañeda et al. (2007) and Sánchez-Franco and Roldán (2005) applied TAM to explain the revisiting behaviour towards a website. The result revealed a significant relationship between attitudes towards behavioural intention (revisit). Bruner and Kumar (2002) took advantage of a new area of consumer behaviour by investigating the relationship between attitude towards the Internet and attitude towards the website. Jarvenpaa et al. (2000) had also stressed the importance of the concepts of attitude in explaining consumer behavior in the context of an online setting.

Various studies have concentrated on the relation between attitude to advertisements and attitude to the sponsor's brand (Lutz 1985). Research by Balabanis and Reynolds (2001) demonstrated the existence of this relationship for Internet users as well, and suggested that attitude to the sponsoring brand transfers to attitude for the use of a website. MacKenzie et al. (1986) proposed four alternative models and the model posits a relationship between attitude to the brand and attitude to the advertisement.

\subsection{Behavioral Intention}

Christy et al. (2005) separated online consumer behavior into five domain key areas including individual/consumer characteristics of the intention and adoption of IS/IT. In this context, Goldsmith and Bridges (2000) and Khalifa and Limayem (2000) found that personal innovativeness is a personality trait that explains consumer online buying. Conversely, Gefen (2002) identified consumer trust and consumer satisfaction as the key antecedents of re-purchases behavior.

According to Li and Zhang (2006), customers still have to decide whether to buy a product or service online, where (specifically) to shop, and how much to spend. As expected, behavioural intention is a potent predictor of shopping behavior at a specified e-store (Pavlou 2003; Suh \& Han, 2003). Nevertheless, Liang and Lai (2002) and Li and Zhang (2006) confirmed that better e-store features such as lower product price, best website design and better store reputation motivate customers' shopping behavior at a specific store. Furthermore, some 
empirical studies have found that customers' beliefs about the website and product attributes significantly impact the shopping behavior (Bhattacherjee, 2001).

The relationship of purchase intention with actual behavior is also common and has been empirically tested in the hospitality and tourism businesses (Bigne' et al. 2001;Wong and Law 2005; Zabkar et al. 2010; Rong et al. 2011). Using 1056 visitors from four tourist destinations, Zabkar et al. (2010) found that destination attributes affect the perceived quality of tourist offerings, which are then significantly related to satisfaction as well as visitors' behavioral intentions. Similarly, Law and Hsu (2005) found that customers viewed information for reservation as the most important dimension and room rates as the most important attribute. Surprisingly, this research also revealed that customers' purchase intentions are affected by high quality accommodations and website quality.

\subsection{Post-Purchase}

Service delivery in this stage is defined as the extent to which the site's promises about order delivery and item availability are fulfilled (Parasuraman et al. 2005). According to Smith (2000), customer concern in online shopping is fulfilling the transaction and delivering the product. This is due to the spatial and temporal separation between buyers and sellers where sometimes the exchange of money and goods is not simultaneous, so the delivery risk is an issue of concern for customers (Smith et al. 2000). Based on Zeithaml et al. (2002), having products in stock, delivering the products within the time frame promised, and accuracy of service promises are attributes of this fulfillment's factor. They added that delayed delivery may have a negative effect on satisfaction. According to Yang and Fang (2004), the two keys of service quality connected to customer satisfaction are the accuracy of the order fulfillment and keeping service promises. Besides keeping promises about the order delivery, the efficiency of service delivery has also been evaluated by the proper condition of the product (Meuter et al., 2000) and item presentation evaluation. The product should be delivered well-packaged and customers should receive the product as seen on the website (Parasuraman et al., 2005).

Since being restricted in communications with customers due to the absence of a salesperson (unlike conventional shopping), it is tremendously important for e-retailers to respond to each inquiry and problem presented by customers. Supporting customer service is thus needed. Supporting customer service is recognized in this phase as one of the factors that contribute to satisfaction in e-retailing. It is measured by the ability to provide appropriate problem-solving information to customers, providing online guarantees, and compensation. Customers expect that online stores will respond promptly to their inquiries (Liao \& Cheung, 2002).

\subsection{Point-of-Purchase versus Post-Purchase}

Many studies have differentiated the stages of electronic purchase; for example, Cao and Gruca (2004) divided online purchase into two stages, which are the pre-purchase and post-purchase stages. According to them, the activities involved in pre-purchase are to: navigate the website, make a choice, make a decision, make a payment and provide the information on status of delivery. Meanwhile, activities that occur in post-purchase are delivery and customer support.

A similar study conducted by Alzola and Robaina (2010) also distinguishes two phases in electronic commerce which are pre-sale and post-sale. In pre-sale, three dimensions are involved (design, information and costs) and two dimensions are involved at post-sale (delivery and guarantee). This study seeks to identify the impact of pre-sale and post-sale factors on online purchasing satisfaction and the results show that the dimensions involved in pre-sale have a significant impact on the dimensions in post-sale. In other words, dissatisfied customers at the pre-sale phase will have an effect on the post-sale phase (e.g., spread negative things to others, do not intend to revisit). Conversely, Posselt and Gerstner (2005) found that post-purchase has a much stronger effect on customer satisfaction and repurchase intention and overall rating compared to service delivered in the pre-sale phase.

Chae et al. (2006) in their study revealed that there was a significant relationship in clothing especially on pre-purchase satisfaction with post-purchase satisfaction among women who participated in tennis. As a result, comfort was identified as the clothing attribute that had the most effect before and after purchasing tennis apparel.

In this study, the researcher divided electronic commerce into two phases, which are point-of-purchase and post-purchase which are important stages in understanding online purchases. Point-of-purchase is measured as the time when customers purchase a product while post-purchase is measured after they have received the product. The researcher is interested in consumer attitudes at point-of-purchase, instead of the pre-sale stage, for capturing respondents' true evaluation of factors influencing the close of an online apparel transaction. 
Responses obtained at the pre-sale stage tend to reflect attitudes of respondents prior to their purchase actions and the value judgements provided by these respondents at this stage may be provisional and differ from their evaluation at point-of-purchase. Therefore, to minimise potential deviation and to ensure an appropriate representation of actual experience, this study focuses on the point-of-purchase stage. This study also looks at consumer attitudes at the post-purchase stage to capture respondents' true subjective evaluation of their experience in regard to delivery service and customer service on overall satisfaction after the respondents have received the products they have purchased and have been exposed to the level of post-purchase service.

Based on the preceding literature review and finding, the research model of the present research is shown in Figure 4. Based on Figure 4, the model was divided into two phases, which were at point-of-purchase and post-purchase.

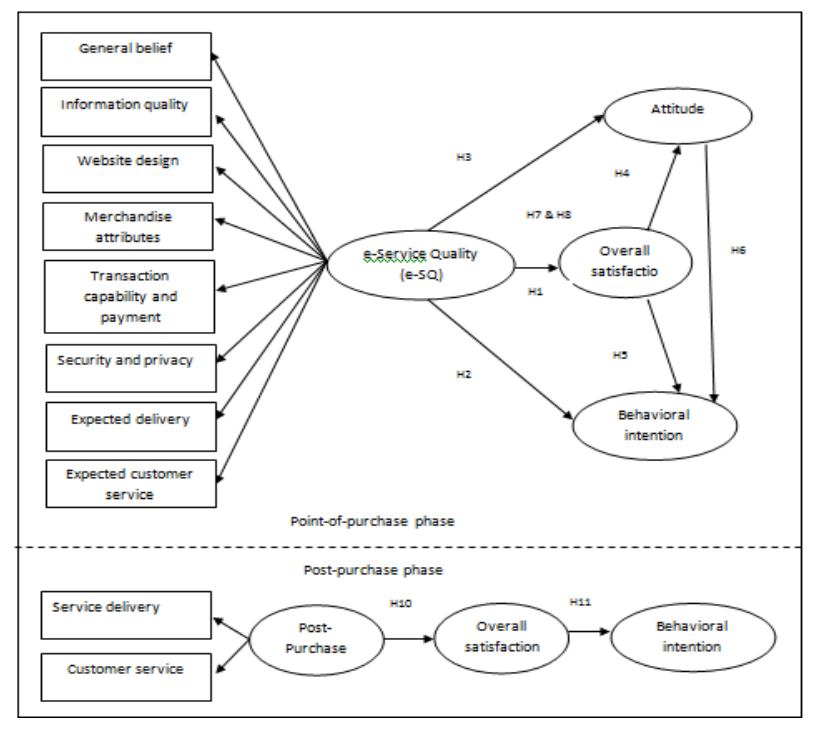

Figure 4. Research model

\section{Conclusion}

Ling et al. (2011) stated that due to the emergence and growth of the Internet in Malaysia, the development of electronic commerce (EC) has become an important trading element in changing the way of doing business from traditional markets to online markets. In fact, the growth of the Internet has created many opportunities for businesses and individuals to explore new ways of life where online business is a key aspect of these new forms of living (Har \& Eze, 2011). According to Jehangir et al. (2011), it could not be denied that e-commerce and Internet technologies have an impact on the firm's performance. The advantage of e-commerce is due to access to the global market and suitable for all types of businesses (Jehangir et al., 2011). For instance, not only are products now available in online businesses but customers are also showing an increasing interest in online service businesses. One of the impacts of Internet technology is that it has enabled businesses to easily reach consumers without geographical boundaries. Simply put, e-commerce comprises the online transactions of business, featuring the links between the computer systems of the vendor, host and buyer. The e-commerce growth sector in Malaysia is stimulated by the National broadband initiative (Hassan \& Ali, 2012). A report survey conducted by International Data Corporation (IDC) in 2007 indicated that overall e-commerce spending in Malaysia had grown to RM15.3 billion in 2009 (Yee \& Seong, 2009). Online buyers in Malaysia also rise year by year. As reported in a news article (The Star) in 2010, Malaysians spent RM1. 8bil on online shopping (Ho 2011) and this figure is expected to triple in three years' time. Ho (2011) added that Malaysian people were spending more on local websites with transactions recorded up to RM825 million compared to foreign websites which recorded only RM627 million in receipts last year. This can be a positive sign for the Malaysian economy especially in motivating new and existing local entrepreneurs to venture into online business models as supported by Hassan and Ali (2012).Thus, this study designed a research model by identifying the factors that influence customer satisfaction and their intentions in online apparel at different stages, which are at point-of-purchase and post-purchase. Besides, Buying apparel online represents a new form of consumer 
behavior in the computer-mediated environment and online retailers are keen to understand this behavior for attracting and retaining their consumers in the competitive online landscape.

\section{References}

Akinci, S., Atilgan-Inan, E., \& Aksoy, S. (2010). Re-assessment of E-S-Qual and E-RecS-Qual in a pure service setting. Journal of Business Research, 63(3), 232-240. http://dx.doi.org/10.1016/j.jbusres.2009.02.018

Balabanis, G., \& Reynolds, N. L. (2001). Consumer attitudes towards multi-channel retailers' web sites: the role of involvement, brand attitude, internet knowledge and visit duration. Journal of Business Strategies, 18, $105-132$.

Barrutia, J. M., \& Gilsanz, A. (2009). E-Service quality: overview and research agenda. International Journal of Quality and Service Sciences, 1(1), 29-50. http://dx.doi.org/10.1108/17566690910945859

Bauer, H. H., Falk, T., \& Hammerschmidt, M. (2006). E-TransQual: A transaction process-based approach for capturing service quality in online shopping. Journal of Business Research, 59(7), 866-875. http://dx.doi.org/10.1016/j.jbusres.2006.01.021

Bhattacherjee, A. (2001). Understanding information systems continuance: An expectation-confirmation model. MIS Quarterly, 25(3), 351-370. http://dx.doi.org/10.2307/3250921

Bigne, J. E., Sa'nchez, M. I., \& Sa'nchez, J. (2001). Tourism image, evaluation variables and after purchase behaviour: inte-relationship. Tourism Management, 22(6), 607-616. http://dx.doi.org/10.1016/S0261-5177(01)00035-8

Carlson, J., \& O' Cass, A. (2010). Exploring the relationships between e-service quality, satisfaction, attitudes and behaviours in content-driven e-service web sites. Journal of Services Marketing, 24(2), 112-127. http://dx.doi.org/10.1108/08876041011031091

Coker, B. (2013). Antecedents to Website Satisfaction, Loyalty, and Word-of-Mouth. Journal of Information $\begin{array}{lllll}\text { Systems and } & \text { Management, }\end{array}$ http://dx.doi.org/10.4301/S1807-17752013000200001

Davis, F. D., Bagozzi, R. P., \& Warshaw, P. R. (1989). User acceptance of computer technology: a comparison of two theoretical models. Management Science, 35(8), 982-1003. http://dx.doi.org/10.1287/mnsc.35.8.982

Delafrooz, N., Paim, L. H., Haron, S. A., Sidin, S. M., \& Khatibi, A. (2009). Factors affecting students' attitude toward online shopping. African Journal of Business Management, 3(5), 200-209.

Dellaert, B., \& Kahn, B. (1999). How Tolerable is Delay? Customers' Evaluations of Internet Web Sites and Waiting. Journal of Interactive Marketing, 13(3), 41-54. http://dx.doi.org/10.1002/(SICI)1520-6653(199924)13:1<41::AID-DIR4>3.0.CO;2-S

Devaraj, S., Fan, M., \& Kohli, R. (2002). Antecedents of B2C channel satisfaction and preference: Validating e-commece metrics. Journal of Information Systems Research, 12(3), 316-333. http://dx.doi.org/10.1287/isre.13.3.316.77

Garver, M. S., \& Gagnon, G. B. (2002). Seven keys to improving customer satisfaction programs. Business Horizons, 45(5), 35-42. http://dx.doi.org/10.1016/S0007-6813(02)00241-0

Han, K. S., \& Noh, M. H. (2000). Critical failure factors that discourage the growth of electronic commerce. International Journal of Electronic Commerce, 4(2), 25-43.

Haque, A., \& Khatibi, A. (2006). The study of the behaviour of Malaysian consumers towards online shopping. Asian Journal of Information Technology, 5(1), 12-19.

Hassan, D., \& Ali, S. (2012). Exploring e-commerce activity in Malaysia: Challenges and opportunities. Journal of Economics and Sustainable Development, 3(10), 48-53.

Ho, S. (2011). Malaysian people spent RM1.8bil shopping online in 2010.

Holloway, B. B., \& Beatty, S. E. (2008). Satisfiers and Dissatisfiers in the Online Environment: A Critical Incident Assessment. Journal of Service Research, 10(4), 347-364. http://dx.doi.org/10.1177/1094670508314266

Jarvenpaa, S., Tractinsky, N., \& Vitale, M. (2000). Consumer trust in an internet store. Journal of Information Technology and Management, 1, 45-71. http://dx.doi.org/10.1023/A:1019104520776 
Jarvis, C., MacKenzie, S., \& Podsakoff, P. (2003). A critical review of construct indicators and measurement model misspecification in marketing and consumer research. Journal of Consumer Research, 30, 199-218. http://dx.doi.org/10.1086/376806

Jehangir et al. (2011). Towards digital economy: The development of ICT and e-commerce in Malaysia. Modern Applied Science, 5(2), 171-178. http://dx.doi.org/10.5539/mas.v5n2p171

Jin, B., Park, J. Y., \& Kim, J. (2008). Cross-cultural examination of the relationships among firm reputation, e-satisfaction, e-trust, and e-loyalty. International Marketing Review, 25(3), 324-337. http://dx.doi.org/10.1108/02651330810877243

Kim, S., \& Stoel, L. (2004). Apparel retailers: website quality dimensions and satisfaction. Journal of Retailing and Consumer Services, 11(2), 109-117. http://dx.doi.org/10.1016/S0969-6989(03)00010-9

Kotler, P. (1991). Marketing Management: Analysis, Planning, Implementation and Control (6th ed.). United States of America: Prentice-Hall.

Kugan. (2011). Malaysia: 17.5 million Internet users, 5 million on broad band, 10 million on 3G. Retrieved 8th August, 2012, from http://www.malaysianwireless.com/2011/06/malaysia-broadband-3g-users/

Kuo, H. M., \& Chen, C. W. (2011). Application Of Quality Function Deployment To Improve The Quality Of Internet Shopping Website Interface Design. International Journal of Innovative Computing, Information and Control, 7(1), 253-268.

Law, R., \& Hsu, C. H. C. (2005). Customers' perceptions on the importance of hotel web site dimensions and attributes. International Journal of Contemporary Hospitality Management, 17(6), 493-503. http://dx.doi.org/10.1108/09596110510612130

Lee, M. Y., Kim, Y. K., \& Fairhurst, A. (2009). Shopping value in online auctions: Their antecedents and outcomes. Journal of Retailing and Consumer Services, 16(1), 75-82. http://dx.doi.org/10.1016/j.jretconser.2008.11.003

Li, N., \& Zhang, P. (2006). What makes customers shop online? The technology of electronic customer relationship management. India: Pearson.

Liao, Z., \& Cheung, M. T. (2002). Internet based e-banking and consumer attitudes: an empirical study. Information \& Management, 39(4), 283-295. http://dx.doi.org/10.1016/S0378-7206(01)00097-0

Limayem, M., \& Khalifa, M. (2000). What Makes Consumers Buy from Internet? A Longitudinal Study of Online Shopping. IEEE Transactions on Systems, Man \& Cybernetics: Part A, 30(4), 421. $\mathrm{http}: / / \mathrm{dx}$.doi.org/10.1109/3468.852436

Loiacono, E. T., Watson, R. T., \& Goodhue, D. L. (2007). Web Qual: An instrument for consumer evaluation of Web sites. International Journal of Electronic Commerce, 11(3), 51-87. http://dx.doi.org/10.2753/JEC1086-4415110302

MacKenzie, S., Podsakoff, P., \& Jarvis, C. (2005). The problem of measurement model misspecification in behavioral and organizational research and some recommended solutions. Journal of Applied Psychology, 90(4), 710-730. http://dx.doi.org/10.1037/0021-9010.90.4.710

Malaysia Blogger. (2008). Malaysia Blogger Directory. Retrieved 10 March, 2010, from http://blogmalaysia.com/Shopping/

Meuter, M., Ostrom, A., Roundtree, R., \& Bitner, M. (2000). Self-service technologies: understanding customer satisfaction with technology-based service encounters. Journal of Marketing, 64(3), 50-65. http://dx.doi.org/10.1509/jmkg.64.3.50.18024

Miniwatts Marketing Group. (2001-2010). Internet World Stats Usage and Population Statistics. Retrieved from http://www.internetworldstats.com/stats.htm

Muyllea, S., Moenaert, R., \& Despontin, M. (2004). The conceptualization and empirical validation of web site user satisfaction. Journal of Information and Management, 41, 543-560. http://dx.doi.org/10.1016/S0378-7206(03)00089-2

Parasuraman, A., Zeithaml, V. A., \& Malhotra, A. (2005). E-SQUAL: a multiple-item scale for measuring consumer perceptions for service quality. Journal of Retailing, 7(3), 12-40.

Pavlou, P. A. (2003). Consumer acceptance of electronic commerce: integrating trust and risk with the technology acceptance model. International Journal of Electronic Commerce, 7(3), 101-134. 
Peterson, R. A., Balasubramanian, S., \& Bronenberg, B. J. (1997). Exploring the implications of the Internet for consumer marketing. Journal of Academy Of Marketing Science, 25(4), 329-346. http://dx.doi.org/10.1177/0092070397254005

Ranganathan, C., \& Ganapathy, S. (2002). Key dimensions of business-to-consumer web site. Journal of Electronic Commerce Research, 6(2), 95-111.

Rong, J., Vu, H. Q., Law, R., \& Li, G. (2011). A behavioral analysis of web sharers and browsers in Hong Kong using targeted association rule mining. Tourism Management.

Seal, C., \& McCartney, D. (1997). Iris recognition for user validation. British Telecommunications Engineering, 16.

Shneiderman, B. (2005). Designing the User Interface. New York: Pearson-Addison Wesle.

Sindhuja, P. N., \& Dastidar, S. G. (2009). Impact of the Factors Influencing Website Usability on User Satisfaction. IUP Journal of Management Research: ICFAI University Press.

Smith, M., Bailey, J., \& Brynjolfsson, E. (2000). Understanding digital markets: review and assessment. In Erik Brynjolfsson and Brian Kahin, (Eds.), Understanding the Digital Economy (pp. 1-37). Retrieved from http://ecommerce.mit.edu/papers/ude

Suh, B., \& Han, I. (2003). The impact of customer trust and perception of security control on the acceptance of electronic commerce

Swaid, S. I., \& Wigand, R. T. (2009). Measuring the quality of e-service: Scale development and initial validation. Journal of Electronic Commerce Research, 10(13-28).

Szymanski, D. M., \& Hise, R. T. (2000). E-satisafction: An initial examination Journal of Retailing, 76(3), 309-322. http://dx.doi.org/10.1016/S0022-4359(00)00035-X

Teo, H. H., Oh, L. B., Liu, C., \& Wei, K. K. (2003). An empirical study of the effects of interactivity on web user attitude. International Journal of Human-Computer Studies, 58(3), 281-305. http://dx.doi.org/10.1016/S1071-5819(03)00008-9

Wang, M., \& Huarng, A. S. (2002). An Empirical Study of the Internet Store Customer Post-Shopping Satisfaction. Special Issues of Information Systems, 3, 632-638.

Weinberg, B. (2000). Don't Keep Your Internet Customer Waiting Too Long at The (Virtual) Front Door. Journal of Interactive Marketing, 30-39. http://dx.doi.org/10.1002/(SICI)1520-6653(200024)14:1<30::AID-DIR3>3.0.CO;2-M

Winter, R. S. (2001). A framework for customer relationship management. Calirfornia Management Review, 43(3), 89-105. http://dx.doi.org/10.2307/41166102

Wirtz, J., Chew, P., \& Lovelock, C. (2012). Pre Purchase Stage Essentials of Services Marketing (2nd ed.).

Wolfinbarger, M., \& Gilly, M. C. (2003). E-TailQ: dimensionalizing, measuring and predicting etail quality. Journal of Retailing, 79(3), 183-198. http://dx.doi.org/10.1016/S0022-4359(03)00034-4

Xia, L., Mengqiao, H., Fang, G., \& Peihong, X. (2008). An empirical study of online shopping customer satisfaction in China: a holistic perspective. International Journal of Retail \& Distribution Management, 36, 919-928. http://dx.doi.org/10.1108/09590550810911683

Yang, Z. (2001). Consumer perceptions of service quality in Internet-based electronic commerce. Paper presented at the 30th EMAC Conference, Bergen.

Yang, Z., \& Fang, X. (2004). Online service quality dimensions and their relationships with satisfaction: A content analysis of customer reviews of securities brokerage services. International Journal of Service Industry Management, 15(3), 302-305. http://dx.doi.org/10.1108/09564230410540953

\section{Copyrights}

Copyright for this article is retained by the author(s), with first publication rights granted to the journal.

This is an open-access article distributed under the terms and conditions of the Creative Commons Attribution license (http://creativecommons.org/licenses/by/3.0/). 